\title{
Grundvandsovervågning 1998-2003 - Rapport fra GEUS 2004
}

\section{Af geolog Per S Sundberg}

Rapporten bygger på resultater og konklusioner om grundvandets tilstand og udvikling baseret på data indsamlet af amterne og amternes årlige rapporter, der udføres som en del af den nationale grundvandsovervågning, GRUMO, samt resultaterne af vandværkernes boringskontrol.

\section{NOVA, NOVANA og GRUMO}

Med vedtagelsen af Vandmiljøplanen i 1987 blev et landsdækkende overvågningsprogram for vandmiljø iværksat. Vandmiljøplanens Overvågningsprogram ændrede ved en senere revision navn til "Nationalt Program for Overvågning af Vandmiljøet 1998-2003”, i daglig tale kaldet NOVA 2003.

En revision af NOVA 2003 har resulteret i det nyeste grundvandsovervågningsprogram NOVANA (Det Nationale

Overvågningsprogram for VAndmiljø og NAtur), der gælder for 2004 - 2009.

GRUMO (Det Nationale Grundvandsovervågningsprogram), som er en del af NOVA 2003, overvåger kvaliteten af grundvandet $i$ de grundvandsmagasiner, hvorfra vandværkerne indvinder råvandet (dvs. fungerer som et varslingssystem for vandværkerne). Én gang årligt indsender amterne analysedata fra bl.a. det Nationale Grundvandsovervågningsprogram og vandværkernes råvandskontrol til GEUS, som er det Nationale Datacenter for Grundvandskemi. GRUMO skal sikre viden om grundvandets tilstand og udvikling med henblik på fremtidig justering af vandværkernes

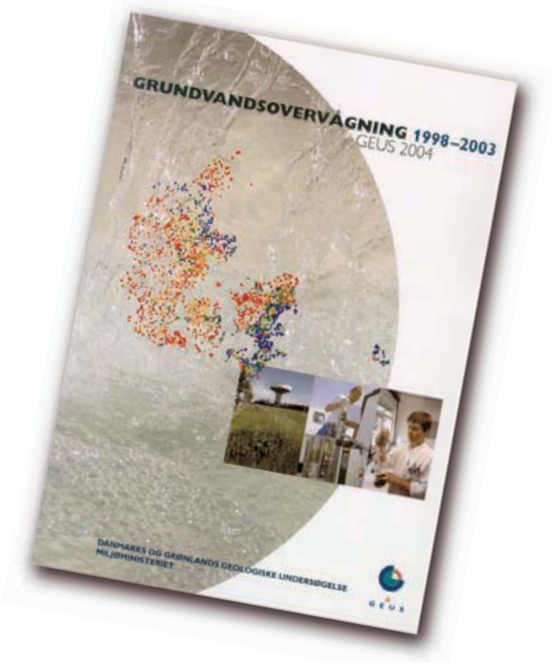

boringskontrol. Der er således etabıeret 70 grundvandsovervågningsområder jævnt fordelt over hele landet. I hvert grundvandsovervågningsområde er der lagt ca. 17 overvågningsindtag, hvorfra man kan analysere grundvandets hovedbestanddele.

\section{Konklusion}

GEUS konkluderer selv på deres hjemmeside om resultaterne fra grundvandsovervågningen under NOVA 2003: "Det gennemsnitlige indhold af nitrat er faldet svagt $i$ grundvand dannet siden 1985 under dyrkede marker. I det grundvand der dannes nu, er indholdet af nitrat i gennemsnit lidt lavere end kravet til drikkevand. Der er imidlertid store variationer fra sted til sted, og mange steder er indholdet af nitrat stadigt højere end drikkevandskravet. I 2003 overskred indholdet af pesticider grænseværdien for drikkevand i ca. 1/10 af de analyserede indtag i grundvandsovervågningen. Antallet af overskridelser er steget svagt de seneste år. Mængden af indvundet vand er faldet siden 1989. Det har mindsket presset på grundvandsressourcen, og mindsket indvindingens påvirkning af vandføringen $\mathrm{i}$ vandløb".

Dertil kan tilføjes, at der ikke er konstateret ændringer af grundvandets indhold af opløst fosfor gennem perioden. Mht. uorganiske sporstoffer er der fundet overskridelser af grænseværdierne i $32 \%$ af indtagene. Det er specielt arsen, der udgør problemet, mens nikkel viser overskridelser i primært Københavns Amt, men også i Roskilde, Vestsjællands og Ribe amter. De pesticider og nedbrydningsprodukter, der findes $i$ indtagene, er specielt BAM, triaziner og triazinnedbrydningsprodukter.

\section{Rapporten}

Rapporten er beregnet for fagfolk, hvorfor det forudsættes et godt grundvandsmæssigt kendskab for at få det fulde udbytte. Imidlertid kan man ved hjælp af de viste figurer og tabeller få et hurtigt overblik over analyseresultaterne. Rapporten er også udstyret med en kort sammenfatning, der opridser de væsentligste tendenser.

Rapporten "Grundvandsovervågning 1998-2003" er redigeret af Lisbeth Flindt Jørgensen og kan købes hos Geografforlaget Aps, Rugårdsvej 55, DK-5000 Odense C, telefon: 6344 1683, fax: 6344 1697, e-post: go@geografforlaget.dk. Pris: Kr. $160 \mathrm{incl}$. moms, excl. forsendelse. ISBN 87-7871-145-2. Den kan også downloades fra Internettet på www.grundvandsovervaagning. $d k$. 